\title{
"Spirit, Safety, and a Stand-off": The Research-Creation Process and Its Roles in Relationality and Reconciliation among Researcher and Indigenous Co-Learners in Saskatchewan, Canada
}

\author{
Myron Neapetung, Lori Bradford, Lalita Bharadwaj
}

\begin{abstract}
Provision of safe water on reserves is an ongoing problem in Canada that can be addressed by mobilizing water knowledge across diverse platforms to a variety of audiences. A participatory artistic animation video on the lived experiences of Elders with water in Yellow Quill First Nation, Treaty Four territory, was created to mobilize knowledge beyond conventional peer-review channels. Research findings from interviews with 22 Elders were translated through a collaborative process into a video with a storytelling format that harmonized narratives, visual arts, music, and meaningful symbols. Three themes emerged which centered on the spirituality of water, the survival need for water, and standoffs in water management. The translation process, engagement and video output were evaluated using an autoethnographic approach with two members of the research team. We demonstrate how the collaborative research process and co-created video enhance community-based participatory knowledge translation and sharing. We also express how the video augments First Nations community ownership, control, access and possession (OCAP) of research information that aligns with their storytelling traditions and does so in a youth-friendly, e-compatible form. Through the evaluative process we share lessons learned about the value and effectiveness of the video as a tool for fostering partnerships, and reconciliation. The benefits and positive impacts of the video for the Yellow Quill community and for community members are discussed.
\end{abstract}

KEYWORDS Indigenous, research-creation, knowledge mobilization, auto-ethnography, story-telling, reconciliation

Environmental health issues are major concerns for Indigenous communities across Canada (Dupont et al., 2014; Bharadwaj et al., 2006). Water resources in Indigenous communities can be difficult to access, and are often contaminated or at risk of contamination due to industrial activities upstream and outside community water borders (Bharadwaj et al., 2006). Contamination of water interferes with traditional activities and the way Indigenous peoples experience the environment (Arquette et al., 2002; Laboucan-Massimo, 2010). Manipulation of water sources through the construction of dams and unmonitoried industrial activity on waterways are long-standing concerns (Blackstock, 2001; Arquette et al., 2002). 
Indigenous people's identities, cultures, and spirituality are intertwined with expressions of the natural world (Windsor and Mcvey, 2005). Water is the lifeblood of Mother Earth; a sacred gift from the Creator that connects all things and must be protected for future generations of all life. Water gives and sustains life. Humans, and in particular women, may have a sacred responsibility to care for water (Kairos and Akaitcho, 2006; Polaris, 2008; Chiefs of Ontario, 2008; McGregor, 2008; Walkem, 2007). These understandings infuse the fabric of Indigenous society and culture, and thus it is easy to understand that when various issues arise with respect to water, many aspects of life are affected.

Indigneous communities are partnering with researchers and organizations to identify contamination of their water sources (Bharadwaj, 2014). Community led research partnerships have directed aquatic cumulative environmental effects monitoring programs. Innovative and meaningful knowledge mobilization of threats to water have been made (Latchmore et al., 2018; Mantyka-Pringle et al., 2017; Baldwin et al., 2017, CWN, 2015). An example is a whiteboard animation video recognized as a culturally-appropriate form of assembling research information on environmental impacts in the Slave River Delta, Northwest Territories (Bradford \& Bharadwaj, 2015).

Emerging digital technologies have enhanced research data collection, engaged youth, and improved dissemination of results. Digital storytelling, a process involving the combination of audio, video, photography, and music in developing short first-person digital narratives, has been demonstrated as an effective way of sharing research knowledge about climate change and environmental and mental health in Indigenous contexts.

This paper describes the collaborative process involved in the creation of an artistic animation video with Yellow Quill First Nation (YQFN). We share how the collaborative video production process enhanced both community-based participatory knowledge translation and sharing, as well as the community's ownership of and access to research information.

\section{Harmonized Storytelling Tradition Indigenous Storytelling}

Oral-based knowledge systems that include storytelling as a primary act predominate among Indigenous groups from Turtle Island, including Anishinaabe, Dene, Saulteaux, Cree, Iroquois, Mi'Chif, and other Nations (Dumbrill \& Green, 2008; Lavallee \& Poole, 2010). Storytelling is often intergenerational in nature; that is, grandparents and other Elders tell stories to youth as a method to teach about ways of life, relationships, practices, cultural beliefs, values, customs, rituals, and history (Corntassell, 2009; Davis, 2014). Lessons are expressed through a range of story genres, from humorous to deeply serious and spiritual (Archibald, 2008). They can focus on social, political and cultural events, practices, and theories. Indigenous storytelling involves expert use of vocal and body expression, the voice, pitch, verbal imagery, facial animation, context, plot and character development, natural pacing of the narration, and meticulous genuine remembrance of the story (Christensen, 2012). Storytellers are held in high regard in many Nations (David, 2004; Archibald, 2008; Iseke \& Brennus, 2011). 


\section{Storytelling as Indigenous Pedagogy}

Storytelling has an advantage of teaching social norms and expectations, moral lessons and reinforcing behaviours for children and youth. Storytelling benefits individuals through identity formation and communities through the weaving of different cultural elements together for feelings of unity (Davis, 2014). Storytelling in Indigenous communities contributes to educational, social and cultural development; maintenance of traditional knowledge; and builds capacity to advocate for change (Battiste, 2002; Piquemal, 2003; Dowell, 2006). Storytelling supports passing of essential ideas from one generation to the next, and it honours customs, knowledge and philosophies (Iseke-Barnes, 2003). It transforms people to agents of change and enhances one's personal resilience (Shoreman, 2009; Hughes-Hassell, 2013).

\section{Challenges to Storytelling in Indigenous Communities}

The erosion of culture, language, participation in traditional economies, and degradation of land and water threaten the continuity of storytelling traditions in Indigenous communities (Heritage Canada, 2005; Jackson, 2018). Changes to ecosystems threaten the resilience, and biodiversity of regions, from which stories, totems, icons, characters, and locations are based (Pfeiffer \& Voeks, 2008; Voggesser et al., 2013). Social processes including cultural appropriation and hybridization threaten the values and 'sacredness' of stories through tensions between story keepers and usurpers (Taylor, 1997; Owen, 2008). The internet is a competing interest against mentorship by Elders for Indigenous youth (Rice, Haynes, Royce, \& Thompson, 2016). The internet, while providing advantages of social connectivity, enhanced access to knowledge, and other opportunities for Indigenous people, is countered by its pervasiveness, unmoderated online racism and abuse directed toward Indigenous people, cyberbullying, and difficulties of legal regulation and policing (Radoll, 2012; Rice et al., 2016). Additional issues include who owns and controls Indigenous knowledges (Schnarch, 2004; Ball \& Janyst, 2008). In some Indigenous communities, there is both the desire to work with academics and other researchers to support the maintenance of Indigenous knowledges and practices, and the fear of losing control of community-held knowledge and practices to the wider world without appropriate attribution or community members' permission for that information to be shared (Castleden, Morgan, \& Lamb, 2012; Ninomiya et al., 2017). More tension is brought forward from academics who need to publish work in particular pathways to advance in their careers (Stiegman \& Castleden, 2015; Bradford, Bharadwaj, \& Lindenschmidt, 2016). Academics are beginning to provide lessons on alternate pathways to mobilize knowledge that may be accepted institutionally and seen as legitimate forms of publication (see for example, Castleden, Hart, Cunsolo, Harper, \& Martin, 2017). However, more stories of practical experiences are needed to contribute to guiding principles across research and non-research contexts.

\section{Some Solutions}

There is a need to develop policies and practices that support and maintain the existence of Indigenous languages, knowledge and traditions (Simpson, 2004; Lowan, 2012). Educational curricula that blend Western science with Indigenous environmental knowledge, support for 
the creation and delivery of Indigenous language, field experiences courses, and Elder-inresidence programs have contributed to that end (Norris, 2006; Brook and McLachlan, 2008; McCoy, Tuck and McKenzie, 2017). Ways of how to overcome knowledge translation problems using techniques that embrace storytelling as a traditional practice, and also take up internetbased technologies to share that information in ways that attract youth, remain culturally harmonized, and meet the needs of academics on co-learning journeys with Indigenous groups are needed (Bradford and Bharadwaj, 2015; Castleden et al., 2017; Saini, 2017).

\section{Evolution of Collaborative Research Partnership}

This project was borne out of a larger collaborative Indigenous-led research program that has evolved over 15 years. A research relationship with the Federation of Sovereign Indian Nations (FSIN) and individual Saskatchewan First Nations, built on trust, co-operation, and mutual respect, grew from a community-driven environmental health project in 2004. Subsequently, a team (the Safe Water for Health Research Team, herafter termed SWHRT) of Indigenous people representing members from First Nations, Federation of Sovereign Indigenous Nations and Tribal Councils, academics, members of the Saskatchewan Research Council, and federal and provincial governments was formed and members met regularly to plan community-driven environmental health initiatives. Through conversations and planned workshops, research questions and objectives for this work emerged naturally.

As a direct outcome of a SWHRT workshop research grants were co-developed and successfully acquired with the aims of gathering narratives from the community on the human dimensions of effective water provision and regulation (Bharadwaj, 2014). Council members were involved in the grant proposal development where they requested the participation of Elders and youth and the gathering of stories about YQFN's Nut Lake.

\section{Community Partners and Context}

Yellow Quill First Nation is located in Treaty Four territory, about 300 kilometers east of Saskatoon and with the main reserve (about 15,000 acres) of 800 people located around Nut Lake. On-reserve is the 250 student K-12 Nawigizigweyas Education Centre, health and social services centres, a general store, a community hall, a water treatment plant, a sewage station, and the Band office.

Nut Lake is a vital and significant water body, and its surrounding territory are critical to the Saulteaux people of YQFN. Their people, spirit, culture, social and traditional livelihoods, economies are tied to the lake, along with the plants and wildlife inhabiting its shores. Councilors and band members have expressed concern about Nut Lake's water quality, given the agricultural land, municipalities, and industries in the same watersheds located upstream. Nut Lake is prone to flooding, increasing local concerns about potential pollutants infiltrating the groundwater drinking water supply. Between 2011 and 2017, unpredictable spring flooding on and around the reserve occurred despite upstream and downstream water control structures. YQFN members continue to feel concerned about their drinking water quality, as well as the impacts of climate change to Nut Lake.

Engaged Scholar Journal: Community-Engaged Research, Teaching, and Learning 


\section{Application of a Multimedia Tool}

The research team was informed research results are often inaccessible to the community. The formats in which results are shared-written words published in reports and journals, or embedded within Powerpoint presentations - were deemed the primary reasons.

Alternative ways to mobilize knowledge were needed. Through an Indigenous-driven research program in the Northwest Territories (Bradford \& Bharadwaj, 2015), an enhanced e-storytelling technique, sharing and disseminating traditional knowledge from a compendium of people as a single-voiced narrative, was co-created. This method was shared with YQFN and others and generated an extremely positive response. YQFN expressed a desire to use this method to share information gathered through the larger research program.

YQFN faces ongoing challenges with access and rights to water. For example, the community has no control of Nut Lake's floodgate mechanisms, leading to ongoing flooding and the lake's eutrophication. Community members expressed desire to gather Elders' knowledge and experiences about water, as a support for their applications to the Truth and Reconciliation process. This act would also ensure Elders' memories were collected and preserved for future generations. This paper describes how arts-based animation projects enhance community-based participatory knowledge translation and sharing processes. We express how this knowledge mobilization project augments youth interest in storytelling, and upholds principles of ownership, control, access and possession of research information. Through an evaluative process, we share lessons learned about the value and effectiveness of the video as a knowledge mobilization tool and the benefits and positive impacts of the video for the YQFN.

\section{Mixed Method Design for Research-Creation and Evaluation Research-Creation}

This study used an engaged mixed method design where research-creation occurred simultaneously with research evaluation as depicted in Figure 1. 


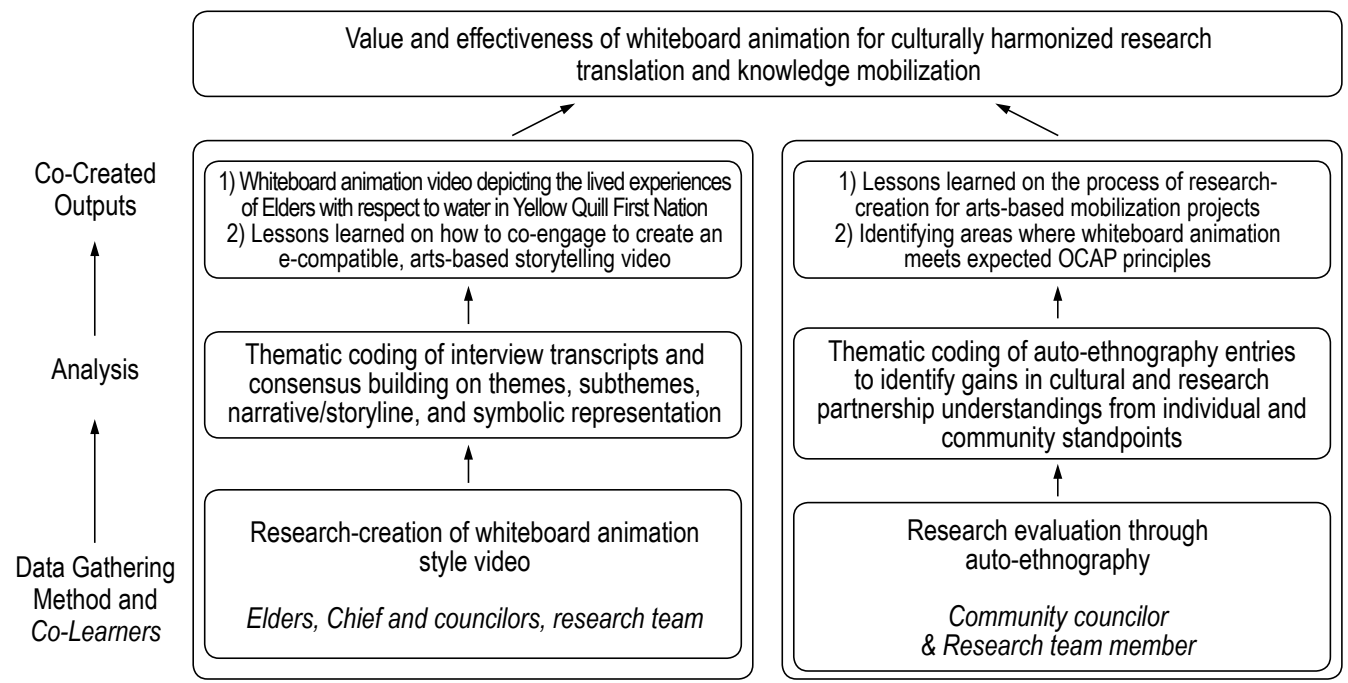

Figure 1. Concurrent Mixed Methods Engaged Research Design for Research-Creation with Yellow Quill First Nation.

Research-creation is an emergent social science practice combining the strengths of contemporary media with the study of pedagogy and practice while engaging in a creative process that builds an artistic work as a direct product (Chapman \& Sawchuk, 2012). Colearners in the research-creation process worked together to build relationships while writing and animating a new community narrative about their experience of changing water access over their lifetimes. Co-learners included 22 Elders, the Chief and council members, media production personnel, researchers and students, and a professional artist. Elders $(\mathrm{N}=2214 \mathrm{M}$, 8F; Average age: 59; Range: 42-81) were interviewed between February 2014 and June 2015. Interviews were recorded, transcribed, and verified by participants between July 2015 and April 2016. Interviews were thematically coded (as per Boyatzis, 1998; Braun \& Clarke, 2006) by two researchers (Bradford, Bharadwaj) and the community council member and coordinator for this project (Neapetung). Three main themes - spirituality of water, the need for water for survival, and stand-offs in water management-were presented to the Chief, other members, and Elders interested in participating in the analysis of interviews. Themes were woven into a narrative by the council member and the researchers, telling the story of each main theme from the perspective of the Elders whose interview content and experiences aligned with that theme. Researchers, Elders, and Chief and council members prepared a table of potential symbols that would appropriately depict aspects of the narrative arising from each main theme. Multiple iterations of symbol identification were completed until co-learners involved in the analysis reached consensus on the symbols. This took 14 months (May 2016-June 2017).

The table of symbols was presented to a contracted professional artist, who met repeatedly with researchers, community coordinator, and council members to gain insights on each symbol and how it represented aspects of each theme. The artist used culturally harmonized 
media identified by community members (willow charcoal on heavy unbleached cotton paper) to draw symbols. She prepared draft drawings of symbols for review, then the team mapped out the symbols to a larger draft 'whiteboard' so the artist could understand sequencing and placement of images on a map where Nut Lake was the central feature. Symbols were placed around the lake in accordance with the Saulteaux guiding principle of the Circle of Life. The media productions team video-recorded the drawing and sped it up to match with narratives that were recorded by community youth and volunteers. The whiteboard animation researchcreation was adapted from a previous protocol (Bradford \& Bharadwaj, 2016).

\section{Auto-Ethnography}

Auto-ethnography, as a method, is a way of investigating how personal stories and experiences elucidate morals and ethics on individual and cultural levels without the pressures of positivistic ideals in academia (Ellis, 2004; Ellis, Adams, \& Bochner, 2011). An approach that systematically analyzes personal experiences to contribute to understanding cultural ones (Ellis et al., 2011). The purpose of auto-ethnography is to examine individual transformations over a specific experience, or range of time to uncover learning in [an] individual(s). In this study, thoughts, beliefs, and learning relating to relationships, research-creation, and research findings of the council member and one key researcher, deeply embedded in the project, were gathered to demonstrate how the relationship between the co-learners evolved. Three questions were explored three times during the course of the project; at inception (June 2016), after creation of the art-animation (June 2017), and at the closing of the project (October 2017). Questions included:

1) What have you gained from this project (so far)?

2) What has the community gained from this experience (so far)?

3) What do you want others to know about your experiences with this project (so far)?

The councilor (Neapetung) recorded his answers on a digital recorder and had a note-taker present to assist with recall of context and talking points. The councilor wanted to ensure his thoughts and words were recorded accurately, and any low speaking was clarified, and backed-up by notes. Recordings were transcribed and both notes and transcriptions verified by Bradford and Neapetung. The researcher (Bradford) kept a journal of her answers which were submitted to the research team for thematic analysis (as per Boyatzis, 1998; Braun \& Clarke, 2006).

\section{Results}

Five sets of findings are discussed: the initial thematic analysis of interviews; the co-created set of symbols to represent themes; the whiteboard animation video ${ }^{1}$; the auto-ethnographical themes; and comparison of findings to principles of ownership, control, access, and possession (OCAP).

\section{Thematic analysis elder interviews}

Three main themes emerged from the 22 Elder interviews and were based around similar

\footnotetext{
${ }^{1}$ https: / /www.youtube.com/watch?v=NqGSm8xFR5A
} 
experiences of the interview cohort.

The theme of Spirit expressed the importance of water as a sacred, spiritual essence contributing to community wellbeing and as a woman's responsibility to protect. Women most often relayed information about the spiritual meaning of water for their community. The water provided them with directives: flooding meant that is was time as a community to undertake cleansing, while drought meant time for fasting to return balance to the cosmological system. Water provided resources for the community including duck eggs, berries, medicines, and a location for gathering as families or as a community. Women discussed how new regulations, policies, and developments have impeded the community's ability to maintain their sacred connections to water. They told stories of difficulties in continuing sacred practices around childbirth, grieving, and in relationship-building with other nations. Much reflection was provided in how changes to the community's water and lake were both a precursor to changes in community member behaviours, as well as a prophecy from Elders of long ago. Two women's voices were selected by consensus to tell the narrative created for the Spirit theme. In YQFN, women are considered the keepers of the spirit of water because of birth stories (we are all born from water through our mothers, and thus women are the keepers of life-spirit through the water of the womb).

The second theme, Safety, discussed the need of water by all species for survival, and was brought forth by the working men who were interviewed. They expressed the practicalities of water; that is, without water there would be no life, no ceremonies, no plants for food or medicine, no hunting and fishing, no transportation, no way to bathe, and there would be a general inability to survive as a community. The men concurred that the waters provided directives — at one point, the community became too large to be supported by the fish, wildlife, and timber in the region and was hence split into three communities, with two groups moving to new lakes. This theme also focused on how stewardship and practicality principles were overpowered by the white-settler need for 'convenience', and how convenient infrastructure such as dams and reservoirs impacted species formerly dependent on natural flows. Utility as a concept superseded morality; this was described in an interview discussing how damage to surrounding non-Indigenous communities was always measured in monetary value and yet no dimensions of damage to Indigenous communities were ever given. The stories told by these Elders also included dramatic moments of escape from changing waters (floods, falling through ice unexpectedly), as well as how changing access and use of water influenced local economies, livelihoods, and food provision. A younger man's voice was selected for this narrative to exemplify the gendered role of being on the land hunting for one's family.

The third theme, Stand-offs, explored how political challenges have influenced the community's identity and cultural sustainability. Stories about political changes were brought forth by co-learners. Some had previous experience as councilors and Chiefs, while others had learned of the experiences of other councilors and Chiefs that had developed into stories told throughout the community as lessons to youth about political process. Many of these stories expressed the lack of voice community members had in political processes such as selling goods through the 'Indian agent', accessing permits to leave reserves, influencing decisions of 
water control boards, and more recently, regaining land entitlements and advocating for treaty rights (including water). A strong male voice was chosen for narration to reflect conventional political leadership in this community.

\section{Symbolic representation of themes}

Once themes were analyzed and consensus was reached on narratives representing each theme, a table of symbols was co-created to guide the artist drawing of the story. Tables 1, 2, and 3 present the selection of symbols representing each theme.

Table 1. Themes, subthemes and symbols for Spirit section

\begin{tabular}{|c|c|}
\hline Section, Theme and Subtheme & Symbols \\
\hline Part 1: Spirit & $\begin{array}{l}\text { These symbols will all be drawn in black around the outside of the } \\
\text { lake and mostly above the lake. Black colour is selected to represent } \\
\text { man, the north, and the winter. }\end{array}$ \\
\hline Introduction & $\begin{array}{l}\text { Draw the outline of Saskatchewan, pinpoint Yellow Quill First } \\
\text { Nation main reserve. This will be the central focus. Pictures will be } \\
\text { added to this central lake shape outline across the video. }\end{array}$ \\
\hline Moved out for school, life events... & $\begin{array}{l}\text { A residential school (Muscowequan - towering brick building), farm } \\
\text { outline, two wedding rings }\end{array}$ \\
\hline Log cabins by the water & Log cabin around the east side of the lake \\
\hline $\begin{array}{l}\text { Water was pure, lived a good } \\
\text { life by the water }\end{array}$ & A gleaming water droplet, happy YQFN face \\
\hline $\begin{array}{l}\text { Water is what we are born from... } \\
\text { gives us life }\end{array}$ & Outline of mother and infant \\
\hline Lake center of the community & People gathered by the water's edge giving tobacco to the lake \\
\hline Shared connections & Drawn arms from the people in the previous piece holding hands \\
\hline Drank water and so did animals & $\begin{array}{l}\text { Draw person with mug dipping into water, horses head bent down } \\
\text { next to it }\end{array}$ \\
\hline Hauled it in barrels, cut ice in winter & Barrel, ice cube, crystal clear and gleaming \\
\hline Hunting animals & Outlines of some animals - beaver, muskrat, moose, elk, deer \\
\hline Bathed, laundry, collection & $\begin{array}{l}\text { Draw scene of people bathing or washing clothes, others collecting } \\
\text { eggs along the shore }\end{array}$ \\
\hline Ceremonies connecting with elements & $\begin{array}{l}\text { Elements (i.e., waves for wind, water droplets for water, sun, moon) } \\
\text { drawn around outside edge of medicine wheel }\end{array}$ \\
\hline $\begin{array}{l}\text { Lived in family groups and } \\
\text { took care of each other }\end{array}$ & Draw family holding hands \\
\hline Learned to respect water very young & Hands holding water with water dripping down from fingers \\
\hline $\begin{array}{l}\text { Water gives spirit - Floods are } \\
\text { cleansing, enhances spirituality }\end{array}$ & Hands holding water splashes the water on a face outline \\
\hline Dam built in the 60 's, changed & Draw outline of what the dam looks like \\
\hline Couldn't drink water anymore & Dirty glass of water \\
\hline
\end{tabular}




\begin{tabular}{|c|l|}
\hline $\begin{array}{c}\text { Water controlled by the whims of other } \\
\text { people (government, water board ...) }\end{array}$ & Outline of man and his hand holding a switch \\
\hline Ceremonies hidden & Curtains drawing closed over people sitting in circle \\
\hline $\begin{array}{c}\text { Sharing resources and getting taken } \\
\text { advantage of }\end{array}$ & $\begin{array}{l}\text { Person giving something to another, but other person holding } \\
\text { fingers crossed behind back }\end{array}$ \\
\hline $\begin{array}{c}\text { Elders predicted the changes } \\
\text { physically and spiritually }\end{array}$ & Elder talking to others sitting and watching \\
\hline Lake as an afterthought & $\begin{array}{l}\text { Child holding hand near water and bigger hand stops that hand from } \\
\text { touching water }\end{array}$ \\
\hline Not respecting other living things & Someone throwing something over shoulder into lake \\
\hline Worrying & Worried face or question marks \\
\hline Afraid of losing the teachings on the & Elder teaching young \\
\hline sacredness of water & \\
\hline
\end{tabular}

\section{Table 2. Themes, subthemes and symbols for Safety section}

\begin{tabular}{|c|c|}
\hline Theme & Symbols \\
\hline Part 2: Safety & $\begin{array}{l}\text { The drawings for this section will be around the outside of the Spirit } \\
\text { drawings and drawn in orange and red to represent the east and west } \\
\text { directions, the cognitive components of people, the summer and autumn, } \\
\text { and a combination of people (settlers and Indigenous people) }\end{array}$ \\
\hline People together around the lake & Draw people gathering around the lake \\
\hline Split into three & Three arrows away from lake \\
\hline $\begin{array}{l}\text { Raised cattle and cut hay, } \\
\text { haying bees }\end{array}$ & Cattle, hay bales \\
\hline Cords of wood & Stacked cords of wood in wagon on road \\
\hline $\begin{array}{c}\text { Convenience, } \\
\text { no sugar no booze... }\end{array}$ & $\begin{array}{l}\text { Draw beer bottle with Circle and slash through (in red), bag of sugar with } \\
\text { circle and slash }\end{array}$ \\
\hline Water was clean & Clean cup of water \\
\hline $\begin{array}{l}\text { Farming and human waste } \\
\text { poured into creek }\end{array}$ & $\begin{array}{l}\text { Barrel of pesticide in a stream that is flowing out to lake: this is a pretty } \\
\text { important symbol for YQFN because of historic events }\end{array}$ \\
\hline $\begin{array}{l}\text { In the fall when it dries up we see } \\
\text { the sludge from the } \\
\text { pesticides and waste }\end{array}$ & Sludge waste, dying plants, bare tree trunks \\
\hline $\begin{array}{c}\text { Animals poisoned and we ate } \\
\text { them, berries and } \\
\text { medicine disappearing }\end{array}$ & $\begin{array}{l}\text { Animals drinking from that stream downstream from where the bottles } \\
\text { are poured }\end{array}$ \\
\hline Greed for money over the earth & Draw planet earth, then dollar sign \\
\hline Everything grew because of water & Draw plants (tiger lillies, bulrushes) along lake edge \\
\hline Fish ladders and hurt fish dying & Fish ladder and fish swimming up it \\
\hline Floodgates making life easer? & $\begin{array}{l}\text { Picture of floodgates or go back to previous one and circle it in new } \\
\text { colour }\end{array}$ \\
\hline
\end{tabular}




\begin{tabular}{|c|l|}
\hline Sopping ground, flooded land & Flooded fields and underground \\
\hline Flooded houses & $\begin{array}{l}\text { Flooded houses, and a calendar which gets flipped and shows next year, } \\
\text { and next year, 2011, 2012, 2013, 2014... }\end{array}$ \\
\hline Town flood and cost & Write 12 million \$ \\
\hline New water plant & Draw outline of new water plant \\
\hline $\begin{array}{c}\text { Teaching kids lessons so } \\
\text { government not seen as a hero }\end{array}$ & $\begin{array}{l}\text { Man in suit with gold medal around neck holding arms up in victory, } \\
\text { person teaching young children in a sharing circle about history and } \\
\text { traditions }\end{array}$ \\
\hline Lessons & $\begin{array}{l}\text { Papers with words like treaty rights, history, contaminants, at school plus } \\
\text { side-by-side image of elder teaching kids }\end{array}$ \\
\hline Thinking - intellect & Hunting, measuring distance with own eyes. Setting traps \\
\hline Listening to Elders & Young kids listening to Elders in a circle \\
\hline $\begin{array}{l}\text { Water is our highway, } \\
\text { floodgates ruin that }\end{array}$ & $\begin{array}{l}\text { Stream going off in distance with canoe floating down, and floodgates } \\
\text { closing across the stream, stars drawn in background }\end{array}$ \\
\hline
\end{tabular}

\section{Table 3. Themes, subthemes and symbols for Stand-Off section}

\begin{tabular}{|c|c|}
\hline Theme & Symbols \\
\hline Part 3: Standoff & $\begin{array}{l}\text { These drawings will be done in blue on outside of circle to represent } \\
\text { the night, winter, emotions }\end{array}$ \\
\hline Argument & Two outlines of people arguing \\
\hline $\begin{array}{l}\text { Flood gate control and } \\
\text { water board }\end{array}$ & $\begin{array}{l}\text { People sitting around board table, Saulteaux person sitting off to side, } \\
\text { vote ensues and people's arms get put up but not the Saulteaux person }\end{array}$ \\
\hline Flooded field & Another flooded field and go back and circle the calendar from before \\
\hline $\begin{array}{l}\text { Community pasture and } \\
\text { good citizens }\end{array}$ & $\begin{array}{l}\text { People working on hay bales together, patting backs of cows, shaking } \\
\text { hands... }\end{array}$ \\
\hline Selling through Indian Agent & $\begin{array}{l}\text { Man in suit with Indian agent label on, permits in pocket or around him, } \\
\text { measuring cattle, pocketing money* another important image here }\end{array}$ \\
\hline $\begin{array}{l}\text { Cutting wood and } \\
\text { selling it in town }\end{array}$ & Person buying a permit and then selling wood to townspeople \\
\hline $\begin{array}{l}\text { Industries (power, water, gas) not } \\
\text { getting permission for use of } \\
\text { Yellow Quill resources }\end{array}$ & Person with 'I don't know' expression or shrugging \\
\hline SaskWater owns the water & $\begin{array}{l}\text { Person holding up paper with words "Water Deed" on it while YQFN } \\
\text { people collect berries and canoe in a lake }\end{array}$ \\
\hline $\begin{array}{l}\text { Reserves paying money to } \\
\text { corporations for resources }\end{array}$ & $\begin{array}{l}\text { Person holding up bills labeled Gas, Electricity, Water and frustrated } \\
\text { expression }\end{array}$ \\
\hline Hands are tied & Two hands tied at wrists \\
\hline Water not in Treaty 4 & $\begin{array}{l}\text { Paper with Treaty Four written on top held in hands of Elder as they sit } \\
\text { looking at lake }\end{array}$ \\
\hline Buying up land, 3 way standoff & $\begin{array}{l}\text { For sale signs drawn around west side of the lake, YQFN people } \\
\text { building it up, but government or other agencies pointing fingers at the } \\
\text { paper and at each other }\end{array}$ \\
\hline
\end{tabular}




\begin{tabular}{|c|l|}
\hline $\begin{array}{c}\text { Paying taxes, milking us for } \\
\text { land that's ours }\end{array}$ & Envelope with stamp labelled 'taxes' and addressed to YQFN \\
\hline $\begin{array}{c}\text { Responsibility to raise children } \\
\text { and grandchildren to protect YQ }\end{array}$ & Children learning from Elder at side of lake \\
\hline Still have culture & Eagle flying away \\
\hline $\begin{array}{c}\text { Kids at school but also } \\
\text { learning at home }\end{array}$ & School building and mom and dad teaching kids at home \\
\hline Water connects us all & Water droplets floating across the sky as if being tossed by a child \\
\hline $\begin{array}{c}\text { Good place to start, teaching } \\
\text { culture and traditions }\end{array}$ & Community members holding hands and talking to one another \\
\hline Worth fighting for & $\begin{array}{l}\text { More people are drawn and more kids and people keep getting added } \\
\text { holding hands, arms around each others waist... until a big group is there }\end{array}$ \\
\hline
\end{tabular}

Specific details on why symbols were selected were at times deemed sensitive. Thus, further details on symbols is not provided at the community's request.

\section{Research-creation output: Artistic animation video}

The next co-created output was the artistic animation-style video. It is not a conventional whiteboard animation. Instead, the drawing process was recorded in its entirety, then sped up to fit the pre-recorded narratives. Community volunteers, recruited from summer staff and students at the Yellow Quill Urban Services office, provided the voice acting. In this case, the artist was video-recorded while she drew the sequence of symbols. Willow chalk and paper were used, as the media did not allow for the quick erasing and rapid movement from one aspect of a story or concept to another. The quick erase concept was also not aligned with the deeply reflective cultural practices expressed by Elders, where mistakes are records of learning and not to be erased. Flute music was suggested as most relevant and appropriate. Soundscaping and editing was completed to finalize the draft video. Sections of video were presented to Chief and Council and interested Elders. Suggestions were incorporated and changes made.

The final copy was presented to Chief and council members. Legal representation provided additional advice for changes necessary for protecting sensitive aspects of local knowledge. A community video launch was held in July 2017 for community members, local school students, and researchers, and with the artist donating the original drawing to the community. DVD copies of the video were gifted to each Elder or his/her family members, the school teachers, and several copies, held by councilors, to the Band office. Ownership of the video was agreed to be held by the community. The video link was shared by the University's media production unit with permission of community councilors who did not yet have a locally-hosted account for hosting the video.

\section{Auto-ethnographical findings}

The auto-ethnographical findings reflect the learning experienced by both a researcher and a 
local councilor, key contributors to the research-creation process. Bradford's research account expressed learning in terms of how to be respectful, relevant, and responsible in co-creating research outputs with Indigenous communities,. Neapetung's auto-ethnographical findings relayed messages about learning to trust researchers, sharing vulnerabilities in order to share the weight of the importance of the work, and leading reconciliation efforts on behalf of his community. These findings developed over the project:

1) What have you gained from this project (so far)?

I found today to be a big step towards building a friendship. I did not know whether the Chief and council members would be supportive of us coming in and suggesting the making of a video from their Elders words and thoughts—like we were selling out their stories. I was afraid that at worst, we would be asked to leave, and told we were being disrespectful of their Elders, some of whom had died since the interviews were done, and at best, told to come back another day. I was surprised to have been welcomed, even after stumbling over my too complicated words. It was right for us to present tobacco, and to listen carefully to the Chief's thoughts about the Delta Ways Remembered video [pilot video presented to group as idea]. There was the immediate ask for the names of the Elders involved in the interviews. I was worried because we couldn't share that info without ethics approval to do so, so I thought the Chief would be upset. We explained why, but I could tell that would be a sore spot. (Neapetung, June 2016)

\begin{abstract}
When they first came in, uh, I thought to myself, 'Here we go again, another research project that doesn't help us.' But it turned out to be different. And the two of them [Bradford, Research Assistant] were so nice and genuine. They brought tobacco. They prayed with us. They listened. The video they showed us was really...um, emotional. Moving. Some of the councilors had a hard time keeping it together. I thought maybe this could work, but I wasn't ready to go all out. The Chief needed some time too. I waited for him to tell me what to do before I called them back. (Neapetung, June 2016)
\end{abstract}

Initial auto-ethnographical entries revealed two challenges; first, from the research side, there was the desire to create a friendship and go about approaching the Chief and council in a respectful way. Secondly, there was a defensiveness from the community's side about getting into a research relationship that may be seen as driven from researcher interest. At the outset of the project, ethical dilemmas complicated the relationships. Within the community, there was the desire to know which Elders had been interviewed, and what they said in those interviews. Researchers were not able to reveal identities because of consent and confidentiality agreements put in place by institutional ethics policies. Overcoming this challenge was deemed a way to demonstrate respect and trust among the co-learners. Elders, originally involved, were contacted and were reminded of their roles in the earlier project. They were re-sent their 
transcripts if desired. If those Elders chose to share their transcripts, it was up to them. In that way, the community members could learn of the Elders who were involved, at their request, not because of researcher action. The drive for this knowledge by the community was not to point fingers (as feared by researchers) but for pride in families whose Elders may have died. Living relatives wanted to be able to be proud of Elder family members for their involvement, as well as have copies of their words as they were nearing end-of-life.

Initial reflections revealed a lack of guidance and familiarity with ways of approaching building a research relationship. While Bradford was uncertain about protocol and formality, Neapetung was unfamiliar about how to enter the relationship in a way that preserved exit opportunities and allowed for time to reflect, and discuss opportunities among community decision makers without researcher pressure.

2) What has the community gained from this experience (so far)?

What we gained from this goes beyond the video...um, the video is great. The teachers use it at the school. Uh, we show it to companies when they come in...we want them to know our history. We gave a copy out to each family. We share the YouTube link. The drawing is still hung up at the school. But, I think Lori [Bradford, researcher] is important. She did things in the right way, a good way. She asks about protocols. Brings tobacco or other important things to our meetings. You know, it's all important. We did it together in a good way. The projects just exploded now. I mean, we're doing some environmental stuff, learning about what's in the lake which we've been curious about for a long time. We're doing the urban movers stuff too. We needed Lori to show us how to get started with that work. The youth, they're interested. Some of them tried to make their own videos. They fiddled around and now they're figuring it out. I think we gained some inspiration. (Neapetung, July 2017)

I don't think it's right for me to talk about what the community has gained, because I'm not in or from the community. But as co-learners, we gained knowledge and experience together. We made mistakes, I made mistakes, but I was forgiven and that felt so good because I was really worried. I think we can keep up the work together now, and I'm not afraid to high five Myron [Neapetung, councilor] over our small victories. I see him at the [Recreation Center] sometimes and we're friends, talking about our kids mostly. I can also text him about upcoming things and know he'll get back to me when he can. We've moved beyond the tip-toe on eggshells part that takes a lot of energy and thought, and are comfortable now. I don't take that for granted, because it reaffirms how important the ongoing effort on our relationship is to supporting each other through our reconciliation journeys. (Bradford, October 2017)

The focus on project outcomes highlighted two findings; firstly, that the video was well received by the community and acted as a stepping stone to further work. Secondly, the video was less important to the councilor and the research team than the relationship between the 
community representatives, and the researchers themselves. At the heart of the analysis, there was a realization of the humanity of both researcher and councilor that was precarious at first, but solidified through mutual challenges faced over time.

3) What do you want others to know about your experiences with this project (so far)?

I'd like others to know that this kind of work is not easy, probably won't produce the journal articles, book chapters, or invitations to international conferences that count as academic career success. But to me, the gratitude of the community is worth more than those things. This work takes time, and energy. It takes emotional commitment. But, I like to be surrounded by a group of people working together for something bigger. In this case, it was doing justice to the lived experiences of the Elders, and also a story that I think, all Canadians should hear. (Bradford, October 2018)

What I want others to know about this...um, is that there are people out there who... uh, do things in a good way. That they [Researchers] came in and followed protocol. That they kept asking about whether they were following protocol and doing things the right way, and, uh, that there was respect. They showed respect to all of us, the students, the Elders, and the Chief. It was the little things too, you know, they baked a cake for the video launch. Lori [Bradford, researcher] answered her phone whenever I called. You know, we've been through it all, and, um, it's hard to figure out who's gonna to be there for the long-haul and who's gonna come and go. And now, it's getting easier for us to figure that out. We needed to let others in, so we can all learn, and heal, so for us too, um, we did some reflecting on how we do things and saw that we, um, we could open up a bit more. We brought a lot of pride back to our community with this video. People were proud of their family members for telling their truths about water, and um, when the video was done we felt like finally, they [researchers] listened. (Neapetung, October 2017)

Entries to this question expressed four themes. First, that while there was difficulty in navigating the initial stages of research relationships, trusting relationships between individuals and groups were ultimately created. Second, maintaining these relationships required ongoing energy and open communication throughout the project and beyond. Both co-learners reiterated the need for continuing to work at relationships and checking-in to be sure expectations were being met. Third, there were reflections from Indigenous partners told through Neapetung that they saw this as a beginning for their healing journey, and that a part of the journey could be done together. Finally, the councilor revealed that as a community, they felt that the researchers had listened. 


\section{Synthesis of results and OCAP principles}

Table 4. OCAP Principles and Responsiveness in this Project

\begin{tabular}{|c|c|c|}
\hline $\begin{array}{l}\text { OCAP } \\
\text { Principle }\end{array}$ & Meaning* & Achievement in this Project \\
\hline Ownership & $\begin{array}{l}\text { Ownership implies the rights of a } \\
\text { Nation and their cultural knowledge, } \\
\text { data, and information. Only the } \\
\text { community or group owns that } \\
\text { information much like individuals } \\
\text { own their personal information. }\end{array}$ & $\begin{array}{l}\text { The video provides ownership of cultural } \\
\text { knowledge in a form aligned with traditional } \\
\text { storytelling principles. The video expresses the } \\
\text { community's spiritual, cultural, personal connection } \\
\text { and lived experiences with water. The video is jointly } \\
\text { owned by the researcher team and the community } \\
\text { with the premise that either owner can share the } \\
\text { video widely. This ownership arrangement was } \\
\text { actively agreed on and is evaluated on an ongoing } \\
\text { basis by both researchers and community members. } \\
\text { The agreement reflected growing trust between the } \\
\text { researchers, councilor, and community. }\end{array}$ \\
\hline Control & $\begin{array}{l}\text { First Nations communities, and } \\
\text { representative bodies are equal } \\
\text { decision makers within all aspects } \\
\text { of the research process and control } \\
\text { resources, research planning and data } \\
\text { management processes. }\end{array}$ & $\begin{array}{l}\text { The research process was co-created with the } \\
\text { community councilors over several months of } \\
\text { interactions prior to the co-development of the } \\
\text { video. The Elders, councilor and researcher worked } \\
\text { jointly directing decisions related to all aspects of } \\
\text { the research process, video creation, and video } \\
\text { sharing. This manuscript was also co-conceived } \\
\text { by the co-learners. Control was an issue when } \\
\text { disclosure of Elders interviewed was requested. } \\
\text { Control was placed back in the community via } \\
\text { individuals who were interviewed vested with } \\
\text { control of their interview transcripts. }\end{array}$ \\
\hline Access & $\begin{array}{l}\text { First Nation communities and } \\
\text { organizations have the right to } \\
\text { oversee and make decisions on } \\
\text { access to information about } \\
\text { themselves regardless of format, } \\
\text { or location where retained. Access } \\
\text { may be realized in practice through } \\
\text { standardized or official protocols. }\end{array}$ & $\begin{array}{l}\text { Throughout the research process councilors } \\
\text { and Elders contributed to the planning of the } \\
\text { research and the development of video themes. } \\
\text { They oversaw the selection of plot, symbols, } \\
\text { narrators, and music for the video. This was an } \\
\text { iterative process where trust and relationships were } \\
\text { built. Appropriate First Nations protocols were } \\
\text { respectfully honoured and verbal agreements were } \\
\text { formulated among our First Nations partners. }\end{array}$ \\
\hline Possession & $\begin{array}{l}\text { Possession refers to the mechanism } \\
\text { by which ownership of information } \\
\text { can be supported and protected. } \\
\text { Possession refers to stewardship } \\
\text { and physical control of community } \\
\text { information. }\end{array}$ & $\begin{array}{l}\text { The whiteboard video provides a means to } \\
\text { support the ownership of cultural and traditional } \\
\text { information in a digital storytelling format. Without } \\
\text { any outside influences, the community can share } \\
\text { the video to wider audiences for purposes that are } \\
\text { meaningful and beneficial to them. }\end{array}$ \\
\hline
\end{tabular}

Source: First Nations Information Governance Centre (2018)

Engaged Scholar Journal: Community-Engaged Research, Teaching, and Learning 
In the past, researchers developed and imposed projects without community engagement or input into the research process. Researchers entered communities, collected data without respect for local culture, and then exited having little or no community interaction or consideration of how research could be shared or even benefit communities. Indigenous people were not involved in research decisions. Through our collaborative research process an iterative cycle of engagement and discussion naturally unfolded to inform our collective decisions about what research information should be collected, who should gather it, maintain it and have access to it. Research was conducted jointly, rather than individually. Research was relevant to the questions and priorities of the community as opposed to researcher interest. Results were co-created and transformed into a knowledge mobilization instrument that respected the community's decisions regarding how research information is to be shared, to whom, how and for what purpose; thereby contributing to the four key OCAP principles. In addition, reflection and meta-anlysis were undertaken to inform future work and to reinforce relationships.

In summary, the results indicate that protocol, shared decision making, and ongoing effort on maintaining and improving relationships were pivotal to the completion of the video, and lessons learned on managing mutually beneficial research-creation work.

\section{Discussion}

The research-creation process guided co-learners toward objectives of gathering Elders knowledge, co-creating an e-compatible output that was culturally harmonized, undertaking a process that involved youth, upholding the principles of OCAP, and providing lessons for other First Nations and research teams looking to undertake research partnerships. From the point of view of the community members, via the councilor, creating the video facilitated reconciliation between the community and the research team. The video itself provided further outcomes; that is, it was deemed a source of pride, a pedagogical tool, a link to Elder knowledge, inspiration for further work and for youth capacity building, as well as the start of a healing journey with YQFN's neighboring municipalities. Anecdotal evidence from Neapetung's autoethnography indicate that youth went on to create artistic animation-style videos. Combination of traditional practices with technological advancements inspired youth.

Other multimedia projects with Indigenous communities had similar results. Emphasis on devoting energy to maintaining accountability and trust in research relationships (Wilson, 2008; Cunsolo Willox, Harper, \& Edge, 2013; MacKenzie, Christensen, \& Turner, 2015), pride in creating a tangible and empowering output, especially with youth (Flicker et al., 2014), and the expressed need to begin reconciliation journeys together during and after the process (Castleden et al., 2017; Wiebe et al., 2017) have been reported. The video enhanced non-local people's access to knowledge about the lived experiences of Elders in YQFN with respect to water, and how colonial practices impacted those living on reserve. There is potential through the internet's pervasiveness and through enhanced social connectivity to provide a spectrum of different perspectives on Canada's history through more videos.

From the point of view of the research team via the key researcher's autoethnography, the 
project provided lessons for her, and other researchers. First, researchers need to be respectful of protocols and governance processes in Indigenous communities above and beyond meeting project objectives and goals. This finding reiterates others (Tobias, Richmond, \& Luginaah, 2013; Castleden et al., 2012; Koster, Baccar, \& Lemelin, 2012). Secondly, culturally harmonized (relevant and contextually-focused) outputs build friendships, and reiterate to communities that researchers are listening (Munns, Mahoney, Miller, \& Whitehead, 2016; Jull et al., 2018). Third, vulnerability can be a strength because of the mutual interdependence in solving project problems, thereby revealing the humanity of co-learners as a common trait (Sinner, 2014; Nilson, 2017).

Finally, sharing research-creation products suffer from two challenges to meeting OCAP requirements; first, in research-creation projects, there can be many voices and influencers for a product. Ownership agreements are needed and require ongoing evaluation and reinforcement. The process of creating these agreements can introduce tension. The second challenge is that researchers may not receive academic credit for these works. Others have provided specific challenges in relation to publishing (Giles \& Casteden, 2008; Bradford, Bharadwaj, $\&$ Lindenschmidt, 2016). These two challenges were overcome through negotiation and the shared realization of greater benefits (trust, friendship, a start towards reconciliation) provided through the video production.

Researchers may feel vulnerable and act cautiously when navigating initial and ongoing relationships with Indigenous groups. In this project, both the councilor and the researcher struggled at first with overcoming emotional challenges. In the researcher's case, it was the fear of making mistakes that might threaten a relationship and, for the councilor, it was the fixation with preserving an exit strategy. With time, patience, and forgiveness, both partners were able to demonstrate leadership toward finding a new path for knowledge creation and sharing. Academia suffers from a lack of intergenerational storytelling on protocol and successes and failures at engaged Indigenous partnerships, although the literature is growing (Zeldin, Larson, Camino, \& O'Connor, 2005; Findlay, Ray, \& Basualdo, 2014; Facer \& Enright 2017). We share this project process as an exemplar for others beginning their own journeys.

\section{Conclusion}

Castleden et al.'s (2017) chapter on reconciliation and relationality in water research provides recommendations for collaborative research with Indigenous groups. We suggest the addition of four recommendations geared toward knowledge sharing to their list:

1) Co-learners have open conversations about their desired knowledge sharing products and processes prior to initiation of the research.

2) Co-learners seek to unite in overcoming the negative aspects of internet-based knowledge sharing via opportunities to upload and share evidence-based researchcreation products widely.

3) Co-learners create processes to discuss potential anxieties about research, for example, ways that Indigenous partners can alert researchers to breaches in

Engaged Scholar Journal: Community-Engaged Research, Teaching, and Learning 
protocol, and researchers can alert Indigenous partners to their institutional constraints.

4) Indigenous partners work with academics to invite more collaboration if desired, catalogue and share knowledge sharing outputs, and create a forum to discuss successful and failed processes.

The video project enhanced community-based participatory processes by facilitating the opportunity for community members to direct the video design and development from interview to widespread sharing. Community members selected key messages, collaborated in the narrative creation, chose symbols and the medium for the artist to convey the story, involved youth and community members in narration for the story, selected music and other post-production enhancements, and directed where and how the video would be broadcast. Interview data was moved from transcript and report form into a harmonized knowledgesharing product so that community members owned a legacy output, in an e-compatible form, aligning with their storytelling traditions. An important finding was that building respectful relationships facilitated the overcoming of individual and culturally-based challenges of trusting one other, and provided foundations for starting healing journeys.

\section{About the Authors}

Lalita Bharadwaj (corresponding author) is an interdisciplinary toxicologist with degrees in physiology and pathology. She is a community engaged scholar working alongside Indigenous communities to co-create solutions aimed at addressing water and health- related challenges. She has over 15 years of experience building respectful research relationships with Indigenous peoples in Canada. Email: lalita.bharadwaj@usask.ca

Lori Bradford is an interdisciplinary applied social psychologist whose work examines inequities and policy change in rural and Indigenous communities in the context of water, health, and wellbeing. She also focuses on the process of inter- and transdisciplinarity and dynamics of research networks across time.

Myron Neapetung is a Councilor from the Yellow Quill First Nation. His education includes Indigenous Studies and Indian Art History. He graduated in 2009 with distinction from First Nations University and holds a teaching certificate from the Indian Teacher Education Program. He encourages respectful, courteous, and collaborative work. "Be positive and only good things will follow." 


\section{References}

Archibald, J. A. (2008). Indigenous storywork: Educating the heart, mind, body, and spirit. Vancouver, BC: UBC Press.

Arquette, M., Cole, M., Cook, K., LaFrance, B., Peters, M., Ransom, J., Sargent, E., Smoke, V., and Stairs, A. (2002). Holistic risk-based environmental decision making: A Native perspective. Environmental Health Perspectives (Supplement 2: Community, Research, and Environmental Justice) 110: 259-264.

Baldwin, C., Bradford, L., Carr, M.K., Doig, L., Jardine, T., Jones, P., Bharadwaj, L., Lindenschmidt, K.E., (2017). Ecological patterns of fish distribution in the Slave River Delta region, Northwest Territories, Canada as relayed by Traditional Knowledge and Western Science. International Journal of Water Resources Development. 34(2), 305-324.

Ball, J., \& Janyst, P. (2008). Enacting research ethics in partnerships with indigenous communities in Canada: "Do it in a good way". Journal of Empirical Research on Human Research Ethics, 3(2), $33-51$.

Battiste, M. (2002). Indigenous knowledge and pedagogy in First Nations education: A literature review with recommendations (pp. 1-69). Ottawa, ON: National Working Group on Education.

Bharadwaj, L. (2014). A framework for building research partnerships with First Nations communities. Environmental Health Insights, 8.

Bharadwaj, L., Nilson, S., Judd-Henrey, I., Ouellette, G., Parenteau, L., Tournier, C., Watson, D., Bear, D., Ledoux, G., and Bear, A. (2006). Waste disposal in First Nations communities: The issues and steps toward the future. Journal of Environmental Health, 68(7), 35-40.

Blackstock, M. (2001). Water: A First Nations' spiritual and ecological perspective. Journal of Ecosystems and Management 1(1): 2-14.

Boyatzis, R. E. (1998). Transforming qualitative information: Thematic analysis and code development. Thousand Oaks, CA: Sage.

Bradford, L. E., \& Bharadwaj, L. A. (2015). Whiteboard animation for knowledge mobilization: A test case from the Slave River and Delta, Canada. International Journal of Circumpolar Health, 74(1).

Bradford, L. E., Bharadwaj, L. A., \& Lindenschmidt, K. E. (2016). Alternative policies for collaborative publishing in natural resource journals. Society \& Natural Resources, 29(11), 1375-1388.

Braun, V., \& Clarke, V. (2006). Using thematic analysis in psychology. Qualitative Research in Psychology, 3(2), 77-101.

Brook, R. K., \& McLachlan, S. M. (2008). Trends and prospects for local knowledge in ecological and conservation research and monitoring. Biodiversity and Conservation, 17(14), 3501-3512.

Castleden, H., Morgan, V. S., \& Lamb, C. (2012). "I spent the first year drinking tea": Exploring Canadian university researchers' perspectives on community-based participatory research involving Indigenous peoples. The Canadian Geographer/Le Géographe canadien, 56(2), 160-179.

Castleden, H., Hart, C., Cunsolo, A., Harper, S., \& Martin, D. (2017). Reconciliation and relationality in water research and management in Canada: Implementing indigenous ontologies, epistemologies, and methodologies. In S. Renzetti \& D. Dupont (Eds.), Water Policy and Governance in Canada (pp. 69-95). New York, NY: Springer. 
Chapman, O., \& Sawchuk, K. (2012). Research-creation: Intervention, analysis and "family resemblances". Canadian Journal of Communication, 37(1), 5.

Chiefs of Ontario. (2008). Water Declaration of the First Nations in Ontario, October 2008.

Christensen, J. (2012). Telling stories: Exploring research storytelling as a meaningful approach to knowledge mobilization with Indigenous research collaborators and diverse audiences in community-based participatory research. The Canadian Geographer/Le Géographe Canadien, 56(2), 231-242.

Corntassel, J. (2009). Indigenous storytelling, truth-telling, and community approaches to reconciliation. ESC: English Studies in Canada, 35(1), 137-159.

Cunsolo Willox, A., Harper, S. L., \& Edge, V. L. (2013). Storytelling in a digital age: Digital storytelling as an emerging narrative method for preserving and promoting indigenous oral wisdom. Qualitative Research, 13(2), 127-147.

CWN (2015). SWEEP- The Slave Watershed Environmental Effects Program. Project Report. Retrieved from: http://cwn-rce.ca/project/sweep-the-slave-watershed-environmentaleffects-program/.

David, J. (2004). Story keepers: Conversations with Aboriginal writers. Owen Sound, ON: Ningwakwe Learning.

Davis, J. (2014). Towards a further understanding of what Indigenous people have always known: Storytelling as the basis of good pedagogy. First Nations Perspectives, 6(1), 83-96.

Dowell, K. (2006). Indigenous Media Gone Global: Strengthening Indigenous identity on and offscreen at the First Nations/First Features Film Showcase. American Anthropologist, 108(2), 376-384.

Dumbrill, G. C., \& Green, J. (2008). Indigenous knowledge in the social work academy. Social Work Education, 27(5), 489-503.

Dupont, D., Waldner, C., Bharadwaj, L., Plummer, R., Carter, B., Cave, K., \& Zagozewski, R. (2014). Drinking water management: Health risk perceptions and choices in First Nations and nonFirst Nations communities in Canada. International Journal of Environmental Research and Public Health, 11(6), 5889-5903.

Ellis, C. (2004). The ethnographic I: A methodological novel about autoethnography. Walnut Creek, CA: AltaMir.

Ellis, C., Adams, T. E., \& Bochner, A. P. (2011). Autoethnography: An overview. Historical Social Research/Historische Sozialforschung, 273-290.

Facer, K., \& Enright, B. (2017). A question of purpose: Engaged learning and the research mission of the university. In J. Sachs \& L. Clark (Eds.), Learning Through Community Engagement (pp. 53-64). Singapore: Springer.

Findlay, I.M., Ray, C., and Basualdo, M. (2014). The ethics of engagement: Learning with an Aboriginal cooperative in Saskatchewan. In B. Jeffrey et al. (Eds.), Journeys in Community-Based Research. Regina, SK: University of Regina.

First Nations Information Governance Centre (2018). OCAP. Retrieved from http://fnigc.ca/ocap. html

Flicker, S., Danforth, J.Y., Wilson, C., Oliver, V., Larkin, J., Restoule, J.P., Mitchell, C., Konsmo, E., Jackson, R., and Prentice, T. (2014). "Because we have really unique art": Decolonizing research with Indigenous youth using the arts. International Journal of Indigenous Health, 10(1), 16. 
Giles, A. R., \& Castleden, H. (2008). Community co-authorship in academic publishing: A commentary. Canadian Journal of Native Education, 31(1), 208.

Heritage Canada (2005). Towards a new beginning: a foundation report for a strategy to revitalize First Nation, Inuit and Métis Languages and Cultures. Report to the Minister of Canadian Heritage by The Taske Force on Aboriginal Languages and Cultures. Ottawa, ON: Canadian Heritage.

Hughes-Hassell, S. (2013). Multicultural young adult literature as a form of counter-storytelling. The Library Quarterly, 83(3), 212-228.

Iseke, J., \& Brennus, B. (2011). Chapter sixteen: Learning life lessons from Indigenous storytelling with Tom McCallum. Counterpoints, 379, 245-261.

Iseke-Barnes, J. (2003). Living and writing indigenous spiritual resistance. Journal of Intercultural studies, 24(3), 211-238.

Jull, J., Mazereeuw, M., Sheppard, A., Kewayosh, A., Steiner, R., \& Graham, I.D. (2018). Tailoring and field-testing the use of a knowledge translation peer support shared decision making strategy with First Nations, Inuit and Métis people making decisions about their cancer care: A study protocol. Research Involvement and Engagement, 4(1), 6.

Kairos \& Akaitcho Dene (2006). Report on the Tu Cho International Indigenous Water Rights Conference. Yellowknife, NWT.

Koster, R., Baccar, K., \& Lemelin, R. H. (2012). Moving from research ON, to research WITH and FOR Indigenous communities: A critical reflection on community-based participatory research. The Canadian Geographer/Le Géographe canadien, 56(2), 195-210.

Laboucan-Massimo, M. (2010). Rights and roots: Addressing a new wave of colonialism. In L. Simpson and K.L. Ladner (Eds), This is an Honour Song: Twenty Years Since the Blockades. Arbeiter Ring Publishing: Winnipeg, MB.

Latchmore, T., Schuster-Wallace, C. J., Longboat, D. R., Dickson-Anderson, S. E., \& Majury, A. (2018). Critical elements for local Indigenous water security in Canada: a narrative review. Journal of water and health, 16(6), 893-903.

Lavallee, L. F., \& Poole, J. M. (2010). Beyond recovery: Colonization, health and healing for Indigenous people in Canada. International Journal of Mental Health and Addiction, 8(2), 271281.

Lowan, G. (2012). Expanding the conversation: Further explorations into indigenous environmental science education theory, research, and practice. Cultural Studies of Science Education, 7(1), 71-81.

MacKenzie, C. A., Christensen, J., \& Turner, S. (2015). Advocating beyond the academy: Dilemmas of communicating relevant research results. Qualitative Research, 15(1), 105-121.

Mantyka-Pringle, C., Jardine, T., Bradford, L. Bharadwaj, L, Lindenschmidt, K.E., Doig, L., Jones, P., Somers, G., Kelly, E., Fresque-Baxter, J., and SRDP. (2017). Bridging science and traditional knowledge to assess cumulative impacts of stressors on aquatic ecosystems. Environment International 102, 125-137.

McCoy, K., Tuck, E., \& McKenzie, M. (Eds.). (2017). Land Education: Rethinking pedagogies of place from Indigenous, postcolonial, and decolonizing perspectives. New York, NY: Routledge.

McGregor, D. 2008. Anishnaabe-Kwe, Traditional Knowledge, and Water Protection. Canadian Woman Studies, 26 (3/4), 26 - 30.

Munns, A., Mahony, A., Miller, K., \& Whitehead, A., 2016. The WA Goldfields Aboriginal Community Antenatal Program-A community midwifery initiative. Collegian, 23(4), 367-372.

Engaged Scholar Journal: Community-Engaged Research, Teaching, and Learning 
Nilson, C. (2017). A journey toward cultural competence: The role of researcher reflexivity in Indigenous research. Journal of Transcultural Nursing, 28(2), 119-127.

Ninomiya, M.E.M., Atkinson, D., Brascoupé, S., Firestone, M., Robinson, N., Reading, J., Ziegler, C.P., Maddox, R., and Smylie, J.K. (2017). Effective knowledge translation approaches and practices in Indigenous health research: A systematic review protocol. Systematic Reviews, 6(1), 34.

Norris, M. J. (2006). Aboriginal Languages in Canada: Trends and perspectives on maintenance and revitalization. Aboriginal Policy Research Consortium International (APRCi). Paper 122.

Owen, S. (2008). The appropriation of Native American spirituality. New York, NY: Bloomsbury.

Piquemal, N. (2003). From Native North American oral traditions to Western literacy: Storytelling in education. Alberta Journal of Educational Research, 49(2).

Pfeiffer, J. M., \& Voeks, R.A. (2008). Biological invasions and biocultural diversity: Linking ecological and cultural systems. Environmental Conservation, 35(4), 281-293.

Polaris Institute. (2008) Boiling Point: A synopsis prepared by the Polaris Institute in collaboration with the Assembly of First Nations and supported by the Canadian Labour Congress. Retrieved May 22, 2008 from www.polarisinstitute.org

Radoll, P. (2012). Cyber-safety and indigenous youth. Indigenous L Bull., 8, 11.

Rice, E. S., Haynes, E., Royce, P., \& Thompson, S. C. (2016). Social media and digital technology use among Indigenous young people in Australia: A literature review. International Journal for Equity in Health, 15(1), 81.

Saini, M. (2017). Participatory Methods for Inuit public health promotion and program evaluation in Nunatsiavut, Canada. (doctoral dissertation). University of Guelph, Guelph, ON.

Schnarch, B. (2004). Ownership, control, access, and possession (OCAP) or self-determination applied to research: A critical analysis of contemporary First Nations research and some options for First Nations communities. International Journal of Indigenous Health, 1(1), 80.

Shoreman, J. (2009). Storytelling \& resilience: A narrative study of youth in care (doctoral dissertation). McMaster University, Hamilton, ON.

Simpson, L. R. (2004). Anticolonial strategies for the recovery and maintenance of Indigenous knowledge. The American Indian Quarterly, 28(3), 373-384.

Sinner, A. (2014). Unfolding Stories. In R. Berman (Ed.), Corridor talk: Canadian feminist scholars share stories of research partnerships (Chapter 10). Toronto, ON: Inanna Publications and Education.

Stiegman, M. L., \& Castleden, H. (2015). Leashes and lies: Navigating the colonial tensions of institutional ethics of research involving Indigenous peoples in Canada. International Indigenous Policy Journal, 6(3).

Taylor, B. (1997). Earthen spirituality or cultural genocide?: Radical environmentalism's appropriation of Native American spirituality. Religion, 27(2), 183-215.

Tobias, J. K., Richmond, C. A., \& Luginaah, I. (2013). Community-based participatory research (CBPR) with Indigenous communities: Producing respectful and reciprocal research. Journal of Empirical Research on Human Research Ethics, 8(2), 129-140.

Voggesser, G., Lynn, K., Daigle, J., Lake, F. K., \& Ranco, D. (2013). Cultural impacts to tribes from climate change influences on forests. Climatic Change, 120(3), 615-626.

Walkem, A. (2007). The Land is dry: Indigenous Peoples, water, and environmental justice. In K. Bakker (Ed), Eau Canada: The Future of Canada's Water. UBC Press: Vancouver, BC. 
Wiebe, S. M., Aguirre, K., Becker, A., Brown, L., Claxton, I., \& Angell, B. (2017). Traveling together? Navigating the practice of collaborative engagement in Coast Salish communities. Engaged Scholar Journal: Community-Engaged Research, Teaching, and Learning, 2(1), 125-144.

Wilson, S. (2008). Relational accountability. In Research is ceremony: Indigenous research methods (pp. 97-125). Black Point, NS: Fernwood Publishing.

Zeldin, S., Larson, R., Camino, L., \& O’Connor, C. (2005). Intergenerational relationships and partnerships in community programs: Purpose, practice, and directions for research. Journal of Community Psychology, 33(1), 1-10. 